\title{
Family Experience in Caring for HIV Positive-Indonesian Migrant Workers: A Phenomenological Study
}

\author{
Nursalam \\ Faculty of Nursing, Universitas Airlangga \\ Surabaya, Indonesia \\ nursalam@fkp.unair.ac.id \\ Abu Bakar \\ Faculty of Nursing, Universitas Airlangga \\ Surabaya, Indonesia \\ Abu.bakar@fkp.unair.ac.id
}

\author{
Ninuk Dian Kurniawati \\ Faculty of Nursing, Universitas Airlangga \\ Surabaya, Indonesia \\ Ninuk.dk@fkp.unair.ac.id \\ Tintin Sukartini \\ Faculty of Nursing, Universitas Airlangga \\ Surabaya, Indonesia \\ Tintin-s@fkp.unair.ac.id
}

\begin{abstract}
This study aimed to investigate the experience of family and relative of Indonesian migrant workers to take care of their family members who are HIV-infected. Method. This study employed a phenomenological hermeneutics methodology. Data were gathered from 9 respondents who were primary carers of HIV-infected patients in two districts in East Java in 2014. Indepth interviews were conducted at the respondents' home to collect data to be analyzed qualitatively. Results. The family and relatives taking care of $\mathrm{HIV}$-infected patients have accepted the patients' conditions although they still feel anxious about possible transmission of HIV disease. Moreover, respondents stated that they had to be very careful not to disclose the patients' status about having infected with HIV due to high level of stigma and discrimination towards HIV patients so that patients could maintain a comfortable social interaction with other family members, relatives and neighbors. Conclusion. Taking care of HIV-infected person provides a rich psychological, social and spiritual experience to the respondents.
\end{abstract}

Keywords-HIV; migrant workers; family; experience

\section{INTRODUCTION}

Human Immunodeficiency Virus (HIV) can cause infection that leads to Acquired Immune Deficiency Syndrome (AIDS) [1]. In 2011, as many as 380,000 Indonesians were infected with this virus [2] The Directorate of Disease Control and Environmental Health of the Ministry of Health Republic of Indonesia (2013) describes that in 2012, there were 21, 511 new HIV cases found, which suggests that HIV findings during 2012 increased just above 500 new cases as compared to 2011 (21,031 cases). In 2011, the regional office of the Ministry of Health in East Java recorded as many as 2,646 inhabitants infected with HIV, which showed an increase from 2,233 inhabitants from the previous year. The East Java Provincial Office [3] also showed that Kediri and Tulungagung districts were included in the red zone distribution of AIDS cases in the province of East Java. Accordingly, the regional office of the Ministry of Manpower, Transmigration and Population
(Disnakertransduk) in East Java has called for vigilance over the spread of HIV and AIDS cases in East Java Province,especially by former Indonesian migrant workers [4]. The number of workers in East Java who were infected with HIV and AIDS has amounted to around 1,700, in which $10 \%$ of them are former migrant workers [5].

The HIV virus can damage the human immune system resulting in infections and illnesses [6]. Psychosocial stress may pose HIV infected-individuals to be more vulnerable to infections and illnesses. On top of HIV infection that damages the system, stress impairs immune system and thus increases the individuals' vulnerability. Psychosocial distress stemmed from three things: (1) social stigma; (2) discrimination against people infected with HIV; (3) delays in treatment and measures needed to prevent opportunistic infections because the infected individual cannot accept the condition and refuse to seek help (Bennett, Traub, Mace, Juarascio, \& O’Hayer, 2016; Li, 2010; Huynh, To, Do, To, \& Nguyen, 2017). Psychological distress may suppress the immune system, thus causing the individual susceptible to diseases [10], [11].

Social support from family members is much needed by patients with HIV and AIDS who are more likely to feel despair when they learn that they suffer from HIV. A positive emotional response from the family can reduce the stress experienced by the patient. The purpose of this study was to capture a picture of the family experience in caring for Indonesian-migrant-workers who were HIV-infected individuals.

\section{METHOD}

The method used in this research was "Phenomenological Study" with hermeneutics approach. This was done by searching for the relationship of the phenomenon after an idea or essence and meaning of the phenomenon was received [12]. Population in this study was the family of Indonesian migrant workers who were infected with HIV in two districts in East Java in 2014. A sample of 9 people were recruited by 
purposive sampling technique. Data were collected for 5 months with assistance from the local office of health department. Data collection was carried out at the patients' family home. Variable of family experience of Indonesian workers infected with the HIV virus was measured using interviews. Data analysis was performed using Collaizi's methods. Not all steps in Collaizi's method were done; the data were not re-clarified to the respondents after the data gathered from the transcribed interviews were collected.

This research has been tested and found worthy of ethics by Ethical Committee of Universitas Airlangga on July 23, 2014, with approval letter No.1245 / UN3.14 / LT / 2014. Ethical principles applied in this study include the principle of beneficence, the principle of justice, and the principle of human dignity.

\section{RESULT}

The study was conducted in Kediri and Tulungagung, East Java Province. Both districts were chosen because many of its residents are migrant workers and many of them later suffered from HIV.

HIV in Kediri is managed by Kediri District Health Office. There were about 600 people living with HIV in the district and some of them were migrant workers. Nevertheless, the exact number of people living with HIV who were migrant workers were not recorded in the health department documents. HIV spreads all over the district. People living with HIV and AIDS (PLWHA) were managed, coached, and monitored by the health authorities in collaboration with NGOs. Based on observations and interviews conducted by the researchers, it can be concluded that in addition to obtaining assistance from nurses and doctors at local hospitals or community health centers, each of PLWHA also accompanied by a friend of PLHIV who were members of the NGOs. The majority of people living with HIV's friends were also HIV infected individuals who were recruited by NGOs to provide the support needed by people living with HIV in the form of psychological support, information support, social support, as well as instrumental support. These supports help PLHIV to get necessary help and make it easier for them to understand therapy as well as other necessary treatments.

Kediri District Health Office assigned a person-in-charge of people living with HIV who was very active in coaching and assisting PLWHA in the region. This officer also manages to have a good relationship with the NGOs so that the monitoring of people living with HIV in the region can be optimized and the relationship among people living with HIV, PLHIV families, NGOs and the Health Department is quite harmonious based on mutual trust and familiarity.

A similar case was discovered in the district of Tulungagung. Coaching system in Tulungagung District Health Office is similar to that done in the area of Kediri since the battle against HIV/AIDS has become a national program in Indonesia.

The research was conducted during August and September 2014 and managed to recruit 9 respondents exposed to family members who were HIV-infected former migrant workers. Demographic data obtained are described as follow:

Table 1 shows that respondents were family members of migrant workers who lived with HIV and AIDS. The average time of the respondents aware that their family members suffered from HIV was 4.2 years. Most of the family members of migrant workers lived with PLHIV, however, there were three respondents who did not live with PLHIV. All respondents were the patients' primary careers, whether or not they lived at the same house with the patients.

Several themes can be generated from the in-depth interviews regarding family experience in caring for PLHIV who were former Indonesian migrant workers, namely: psychological, social and spiritual response.

\section{Psychological Theme}

Psychological response is a response issued as feelings coming out of an individual. Kubler Ross (1974) in Potter, Perry, Stockert, \& Hall (2013) outlines the five stages of a person's emotional reactions to stressors namely 1) denial; 2) anger; 3) bargaining; 4) depression; and 5) acceptance. When a family member disclosed that he/she suffered from HIV, all respondents' first reaction was denial; they did not trust the results of the examination. Examples of the respondents' expressions are as follow:

Respondents 1, "I didn't believe what she said. It couldn't be. I didn't believe she got the disease (HIV). I took her to shamans and traditional healers in case her disease was caused by evil spirits. It took me some time to learn that my niece did suffer from HIV..." (took a deep breath, long paused). Respondents 2, "... first, I could not believe it, but after nearly two years I can finally accept this condition."

After some time, respondents finally had accepted the condition that one of their family members was suffering from HIV. The average time needed by the respondents to express their feelings of acceptance was from 1 to 1.5 years after the PLHIV illness was first diagnosed. Feelings of acceptance were developed after NGOs or attendances of PLWHA conducted home visits to explain about the disease and its transmission. Respondent 5 said, "I think after a year or so I began to understand the situation...after ...almost every day we got visits from this lady (while talked, he pointed at the attendance of PLWHA from an NGO)."

Informational and social supports provided by PLWHA attendance from NGOs and health district officers were very helpful for the respondents to work through the steps of mourning and grieving stemmed from the situation and then peacefully accept the situation and steel themselves to provide necessary support and help for their loved ones who suffered from HIV and or AIDS. Respondent 3 said, “ .... He visited me nearly every day (the PLWHA attendance), accompanied me at the hospital when my wife was hospitalized and in a critical condition due to AIDS. Sometimes he just sat with me, said nothing, and listened to me. At another time, he explained about HIV and AIDS. He had helped me to whole-heartedly accept the conditions of my wife, my wife's illness. I finally realized that I had to help her, whatever she was doing in the 
past was no longer important." The respondent further stated, "I know a lady from the health district officer who has been taking good care of us. She gave me calls, and give me the necessary help... like when I had to take my wife to Surabaya for more advanced treatment, she'd been very helpful all this time.

When we asked respondents' current feeling, all respondents revealed that at this time they still feel anxious that the HIV will spread to another family member, or to themselves because the majority of respondents did not have HIV. Respondents 4 said, "Until now I have not been able to eliminate feelings of anxiety if the disease is transmitted to his children and other family members." Similarly, respondents 5 said, "Until now I am still not willing to have neither myself contracted the deadly disease nor have it transmitted to other relatives."

\section{Social Theme}

Social response is a response issued as feelings coming out of an individual while interacting with the environment. Social adaptive response of individuals who face certain stressors according can be distinguished in three aspects, among others: 1) the social stigma exacerbates depression and negative views about the dignity of individuals; 2) discrimination against people infected with HIV, for example, the refusal to work and home life will also affect the health condition; and 3) the lengths of time spent working through each steps of loss and grieving that come with different levels of intensity may cause a delay in the prevention of opportunistic infection and treatment . The first reaction to learning of the illness (HIV) of the majority of respondents was denial of the reality of the situation and isolating themselves from the world, which they understand as a result of immediate shock. After a while, respondents said that they began to feel inferior and afraid to make contact with relatives and neighbors whom they assumed would not want to interact with them once the truth was revealed. Finally, respondents stated that they could resume their normal life upon realizing that their surrounding communities and neighbors behave normally as actually only a few people or even nobody knows that their loved ones are suffering from HIV. The length of the social situation varied among respondents.

Respondents 9 said, "I didn't dare to leave the house or play with the neighbors ...." The same thing was also expressed by many respondents, including respondent 3 who stated, "I didn't dare to play with my neighbors, but after a week I was back to my normal social life."

At the moment, respondents expressed an entirely normal feeling. It is possible because neighbors or the community do not know the disease suffered by their family members. A respondent mentioned that he had to lie to his relatives and neighbors about his daughter's illness because he was still afraid that they will isolate him and his family. This respondent 6 said, "I have a normal social life with relatives and neighbors. I mingle with them especially when there is an event of salvation (Prayer). When they asked me about my daughter's illness, I told them that my daughter was suffering from lung disease (which was the opportunistic infection of the primary disease). So, I didn't completely lie to them." Only two respondents reveal that they have disclosed the real illness of their family members, and their community has accepted them. Respondents 1 said, "I am currently interacting with neighbors.... Everybody knows that my niece has HIV. There was a time when people wanted to burn her and all of our relatives alive because of HIV, but now we managed to resume our normal social life. I didn't know why. Maybe it was because they have learned many things from television or the government, or maybe they have forgotten that she is (her niece) suffering from HIV because she looks healthy and never displays symptoms of any opportunistic infections. Perhaps, they think that the disease is not so dangerous for them, or maybe they think she has been cured from the illness. I don't know. I have never had the courage to find out the truth".

\section{Spiritual Themes}

Spiritual response is a response reflected through the behavior of individuals that tend to draw them closer to God. Spiritual adaptive response is developed from the concept of Ronaldson (2000) in Nursalam \& Kurniawati (2007). Adaptive spiritual responses include: 1) realistic expectations; 2) steadfast and forbearing; and 3) good at taking lessons. All respondents assert that the condition has drawn them closer to God and made them diligent in performing prayers. All revealed that the patient's illness might as well the God way to make them and the family become a better person. None of the respondents expresses any sign of spiritual distress.

Respondent 2 stated that "After I know that my sister has this disease, I become more religious. As a Moslem, I pray five times a day, which I rarely do before. I believe her illness is a warning from Allah the Almighty that I need to get closer to Him and do more good deeds for other people."

Respondent 3 said, "How could I complain about this unfortunate ordeal when Allah also sent me so many help and support? Many people that I haven't known before, including you, are so helpful; although we still cannot disclose my wife's status to many people, like our close relatives, parents, and neighbors."

Respondents 8 mentioned that "I think this disease has made me and my niece become more diligent in performing prayers. We hardly ever prayed in Mosque before."

\section{DISCUSSION}

This study advances our knowledge of family experience in taking care of their loved one who contracted HIV in three aspects: psychological, social, and spiritual aspects. Taking care of family members who were suffering from HIV provide respondents with not only a complex psychological experience, but also social and spiritual experiences. Among the three experiences, the social experience is hardly felt by the respondents because the majority of patients and respondents conceal the real illness from their relatives and neighbors. This condition reflects stigma and discrimination towards HIV disease.

Psychological response of family member who take care of their love one who was suffering from HIV was varied, but the 
majority of respondents were at the acceptance state. They could accept that their love one was suffering HIV; however the anxiety about the contagious disease was still prominent feeling. The acceptance state felt by the respondents' results in positive feelings i.e contended, do not feel inferior, stay motivated, and feel sincere with the current condition. This finding is consistent with a previous qualitative study by Ayu, Putri, \& Tobing (2016) that found feeling optimistic, be grateful, self-respect, have the right and feel equal with others, and do not want to be treated differently are some of the description of self-acceptance of Balinese HIV people.

The results revealed that respondents isolated themselves from the community and relatives at the time of disease disclosure because they feared of the community reaction due to strong stigma and discrimination to PLHIV. During data collection however, respondents had resume their normal social interaction and there is no state of exclusion from the community. This situation was possible because the PLHIVs and respondents keep the disease close to the public, even to the relatives. Other people did not know the real disease of the PLHIV. This finding suggests that stigma and discrimination to PLHIV is still prominent, preventing the PLHIV from disclosing their status. Waluyo, Sukmarini, \& Rosakawati (2006) assert that lack of public knowledge about HIV / AIDS will trigger stigma on the person of the patient / person suffering from HIV / AIDS. Furthermore, this study found that respondents and the PLHIV only received assistance from the local health care institution and other PLHIV who worked for NGO. This condition reflects discrimination in HIV disease. Literature agree that stigmatisation is still a problem, and it is not only from the community, but also from the health care professional such as nurses and doctors [16], [17]. Stigma have been reported to cause burdens emotionally, physically and financially for people suffering HIV [18].

Spirituality is found to have a correlation with purpose in life [19]. This study revealed that the spiritual response of the respondents was accept and make peace of the condition. A good spiritual response will affect patients' stress. A previous study found that acceptance and spiritual response have a positive correlation with cortisol [20]. Therefore, a nurse need to expand their understanding about spiritual response. McSherry, Cash, and Ross (2004) argue that nurses understanding about spirituality will have an impact for practice. Persaud (2007) also assert that spirituality found to correlate with disease progression by some studies. Further study is required to understand the social experience of people taking care of their loved ones when they have disclosed the HIV disease to the community.

\section{CONCLUSION}

Taking care of HIV-infected person provides a rich psychological, social and spiritual experience to the respondents. Psychologically, respondents are able to accept the patients' illness, while they have also managed to obtain a positive social and spiritual experience.

Mentoring needs to be conducted intensively for patients and families of patients with HIV during the first year by health officers and attendances of PLWHA. Further research is required regarding social experiences in taking care of loved ones once the HIV illness is disclosed publicly in order to understand the steps to be taken to reduce social harassment and discrimination against PLHIV and their loved ones.

\section{REFERENCES}

[1] WHO, "HIV/AIDS," 2013.

[2] WHO, "Data on the Size of the HIV/AIDS Epidemic: Prevalence of HIV among Adults Aged 15 to $49(\%)$ by Country," 2013. .

[3] D. Jatim, "Program Pengendalian Penyakit Menular di Jawa Timur," 2012.

[4] Depkes, "Profil Kesehatan Indonesia 2012," 2013.

[5] Antara, "JATIM tertinggi kasus HIV/AIDS," ANTAR News, 2011.

[6] I. Ayu, K. Putri, H. Tobing, U. Rizkiana, M. F. Parry, J. Stewart, P. Wright, G. X. McLeod, T. O. Famoroti, L. Fernandes, S. C. Chima, A. Waluyo, G. Culbert, J. Levy, K. Norr, A. C. Wagner, T. A. Hart, K. E. McShane, S. Margolese, T. A. Girard, C. Zhang, X. Li, Y. Liu, S. Qiao, L. Zhang, Y. Zhou, Z. Shen, Z. Tang, I. Yang, T. Hiv, Nursalam, N. Kurniawati, R. Persaud, W. McSherry, K. Cash, and L. Ross, "Asuhan Keperawatan Pada Pasien Terinfeksi HIV," AIDS Behav., vol. 18, no. 8, pp. 124131, 2007.

[7] D. S. Bennett, K. Traub, L. Mace, A. Juarascio, and C. V. O'Hayer, "Shame among people living with HIV: a literature review," AIDS Care, vol. 28, no. 1, pp. 87-91, 2016.

[8] L. Li, "Stigma, social suuport and deppression among PLWHA in Thailand," vol. 21, no. 8, pp. 1007-1013, 2010.

[9] V.-A. N. Huynh, K. G. To, D. V. Do, Q. G. To, and M. T. H. Nguyen, "Changes in depressive symptoms and correlates in HIV+ people at An Hoa Clinic in Ho Chi Minh City, Vietnam," BMC Psychiatry, vol. 17, no. 1, pp. $1-7,2017$.

[10] S. . Putra, Psikoneuroimunologi Kedokteran, 2nd ed. Surabaya: Airlangga University Press, 2011.

[11] A. E. Nurdin, "Pendekatan Psikoneuroimunologi," Med. J. Andalas, vol. 34, no. 2, pp. 90-101, 2015

[12] N. Burns and S. Grove, "Introduction to the Qualitative Research Process," in Understanding Nursing Research: Building an Evidence-Based Practice, 5th ed., N. Burns and S. . Grove, Eds. Maryland: Saunders Elsevier, 2011, pp. 72-100.

[13] P. . Potter, A. . Perry, P. . Stockert, and A. . Hall, Fundamentals of nursing, 8th ed. St Louis Missouri: Elsevier Mosby, 2013.

[14] I. Ayu, K. Putri, and H. Tobing, "Gambaran Penerimaan Diri Pada Perempuan Bali Pengidap HIV-AIds," vol. 3 , no. 3, pp. 395-406, 2016.

[15] A. Waluyo, L. Sukmarini, and R. Rosakawati, "Persepsi Pasien HIV/Aids dan Keluarganya Tentang HIV/AIDS dan Stigma Masyarakat Terhadapnya," J. Keperawatan Indones., vol. 10, no. 1, pp. 16-23, 2006.

[16] T. O. Famoroti, L. Fernandes, and S. C. Chima, "Stigmatization of People Living With HIV/AIDS by Healthcare Workers at a Tertiary Hospital in KwaZuluNatal, South Africa: A Cross-Sectional Descriptive Study.," BMC Med. Ethics, vol. 14 Suppl 1, no. Suppl 1, p. S6, 2013.

[17] A. Waluyo, G. Culbert, J. Levy, and K. Norr, "Understanding HIV-Related Stigma Among Indonesian Nurses," J. Assoc. Nurses AIDS Care, vol. 26, no. 1, pp. 69-80, 2015. 
[18] C. Zhang, X. Li, Y. Liu, S. Qiao, L. Zhang, Y. Zhou, Z. Shen, and Z. Tang, "Emotional, Physical and Financial Burdens of Stigma Against People Living With HIV/AIDS in China," AIDS Care, vol. 28, no. sup1, pp. 124-131, 2016.

[19] K. M. Litwinczuk and C. J. Groh, "The Relationship Between Spirituality, Purpose in Life, and Well-Being in HIV-Positive Persons," J. Assoc. Nurses AIDS Care, vol. 18 , no. 3, pp. 13-22, 2007.
[20] Nursalam, N. Kurniawati, A. Bakar, Purwaningsih, and C. Asmoro," "Respons bio-psiko-sosio-spiritual pada keluarga tenaga kerja indonesia yang terinfeksi hiv," $J$. Ners, vol. 9, no. 2, pp. 209-216, 2014.

[21] W. McSherry, K. Cash, and L. Ross, "Meaning of spirituality: Implications for nursing practice," J. Clin. Nurs., vol. 13, no. 8, pp. 934-941, 2004.

[22] R. Persaud, "Spirituality and HIV disease progression," $J$ Gen Intern Med, vol. 22, no. 8, p. 1220, 2007. 